\title{
THE "AEGEAN SETTLEMENT PATTERN" IN COASTAL WESTERN ANATOLIA FROM THE NEOLITHIC AGE TO THE END OF THE 3RD MILLENNIUM BC
}

\section{NEOLITIK ÇAĞ'DAN MÖ 3. BİNYIL'IN SONUNA KADAR BATI ANADOLU SAHIL KESIMININE "EGE YERLEŞIM MODELI"}

\author{
Makale Bilgisi Article Info \\ Başvuru: 02 Aralık 2020 Received: December 02, 2020 \\ Hakem Değerlendirmesi: 04 Aralık 2020 Peer Review: December 04, 2020 \\ Kabul: 20 Aralık 2020 Accepted: December 20, 2020
}

DOI : $10.22520 /$ tubaar2020.27.002

\section{Ümit GÜNDOĞAN *}

\section{ABSTRACT}

Extending over a wide geographical area Anatolia has a rich architectural diversity. The Western Anatolia Region is divided into two sub-regions as Coastal Western Anatolia and Inland Western Anatolia. Even though similar building techniques and similar materials were used in both sub-regions, the settlement patterns differ from each other distinctively. Especially in the 3rd Millennium BC, while buildings opening to the streets were seen in the Western Anatolian coastline, Eastern Aegean Islands, the Sporades Islands, Mainland Greece, The Cyclades Islands and Crete Island, buildings leaning on the defense system in Inner West Anatolia open to the courtyard located in the center of the settlement. When Considered the commercial and cultural relations between the regions in the 3rd Millennium $\mathrm{BC}$, it is seen that a cultural an architectural idea was culturally formed in the area surrounded by the Aegean Sea. This architectural planning system plays an important role in understanding the social structures, organizational forms, hierarchical structures of the societies and the interrelations with the neighboring cultural regions.

Keywords: Early Bronze Age, Western Anatolia, Aegean, Aegean Settlement Pattern, Anatolian Settlement Plan.

\footnotetext{
Arş. Gör. Dr., Department of Archaeology, Faculty of Science and Letters, Batman University, Batman. e-posta: umit.gundogan@batman.edu.tr; umitgndgn@gmail.com ORCID: 0000-0003-4292-2671
} 


\section{ÖZET}

Geniş bir coğrafyaya sahip olan Anadolu, birbirinden farklı oldukça zengin bir mimari çeşitliliğe sahiptir. Anadolu'nun Batı Anadolu olarak adlandırılan bölgesi kendi içerisinde Batı Anadolu sahil kesimi ve İç Batı Anadolu olmak üzere iki bölgeye ayrılmaktadır. Bu iki bölgede birbirine benzer malzeme ve inşaat teknikleri kullanılmış olsa da yerleşim modellerinde belirgin bir farklılık görülmektedir. Özellikle MÖ 3. Binyıl'da Batı Anadolu sahil kesimi, Doğu Ege Adaları, Sporad Adaları, Kıta Yunanistan, Kiklad Adaları ve Girit Adası'nda sokaklara açılan yapılar görülürken, İç Batı Anadolu'da savunma sistemine yaslandırılan yapılar yerleşimin merkezinde bulunan avluya açılmaktadır. MÖ 3. Binyıl'da bölgeler arası ticari ve kültürel ilişkiler düşünüldüğünde, Ege Denizi'nin çevrelediği alanda kültürel bir mimari fikrin oluştuğu görülmektedir. Bu mimari planlama sistemi, toplumların sosyal yapısını, örgütleniş biçimini, hiyerarşik yapısını ve çevre kültür bölgeleriyle olan ilişkilerinin anlaşılmasında önemli rol oynamaktadır.

Anahtar Kelimeler: Erken Tunç Çağı, Batı Anadolu, Ege, Ege Yerleşim Modeli, Anadolu Yerleşim Planı. 


\section{INTRODUCTION - A GENERAL OVERVIEW ON THE ANATOLIAN SETTLEMENT PATTERN}

Settlement patterns and architecture play an important part in exhibiting the social structure, organizational form, hierarchical structure of a society and its connections with other centers in the region as well as displaying its relations with the neighboring cultural regions. The locations of the settlements provide detailed information on the economic structures of the centers, as well. settlement patterns starting from the Neolithic Age to the beginning of the $3^{\text {rd }}$ millennium $\mathrm{BC}$ are examined, no distinct settlement pattern or cultural borders are noted (Fig.1, 2).

Western Anatolia is divided into two sub-regions as Coastal Western Anatolia and Inland Western Anatolia. The building and settlement patterns seen in both sub-regions show that a particular architectural development process has been undergone. Encircled by defense systems and divided by streets and alleys, long houses were built adjacently forming blocks/insulae in Coastal Western Anatolia and in the Eastern

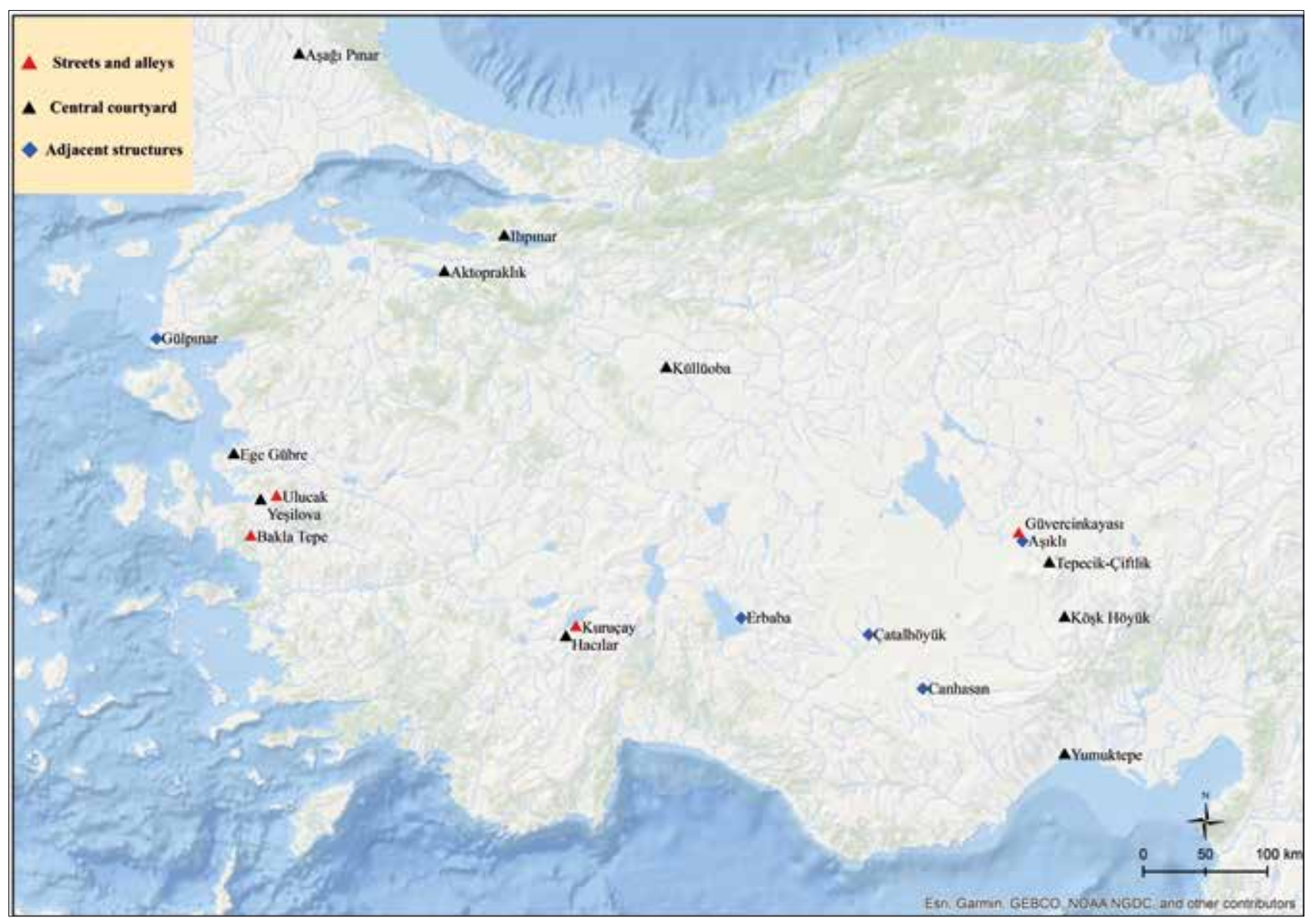

Figure 1: Settlement models in Central and Western Anatolia in the Neolithic and Chalcolithic Age / Neolitik ve Kalkolitik Çăg'da Batı ve Orta Anadolu yerleşim modelleri

Extending over a wide geographical area Anatolia has been home to numerous cultures. The climate and the geographical variation of Anatolia has contributed to the emergence and development of many different cultures. Depending on the climate, topography and the building materials of the region inhabited, these cultures have made up buildings, defense systems and settlement patterns unique to them. This rich cultural diversity has paved the way for the development of different structures and settlement patterns in the societies that lived in the same historical period. For this reason, when the Anatolian
Aegean Islands by the beginning of the $3^{\text {rd }}$ millennium BC. The entrances of the structures built as blocks open onto streets or alleys connected to these main streets. In terms of form, this type of settlement plan composed of streets and alleys is generally discussed in three different systems as radio-centric, linear or rectangular' ${ }^{1}$.

In Inland Western Anatolia, there is a different settlement pattern. The buildings resting on the defense system open onto a central courtyard. This settlement layout known as

Alram-Stern 2004: 261-63; Hüryılmaz 2017; Kouka 2016. 
the "Anatolian Settlement Plan" could be discussed as three different types: radial, elliptic and rectangular. The concept, the "Anatolian Settlement Plan", commonly used among settlement patterns was first expressed by Korfmann. As a result of the data that Korfmann obtained from the Demircihüyük excavations, he used the term, the "Anatolian Settlement Plan" based on the Demircihüyük architectural plan $^{2}$. The presence of similar settlement patterns extending from layers IIA and IIB of Hacilar to Mersin Yumuktepe, Ahlatlibel and Pulur-Sakyol has provided a basis for the use of this term by Korfmann ${ }^{3}$. Fidan has reconsidered Korfmann's concept of the "Anatolian Settlement Plan", and noted that the term corresponds to the settlement planning of only Inland Western Anatolian settlements ${ }^{4}$.

\section{THE WESTERN ANATOLIAN SETTLEMENT PATTERNS}

Many of the settlements in Western Anatolia, favorable for inhabitation since the prehistoric ages in terms of suitable climate and environmental conditions, were mostly established on the plains covered with rich alluvial soil. The fact that these fertile plains have significant agricultural potential is the most important factor for the occupation of the region by humankind. In Coastal Western Anatolia, traces of earliest human activity identified has been attributed to the Lower Paleolithic $\mathrm{Age}^{5}$. Permanent settlements were founded starting from the Neolithic Age. Remains of earliest settlements have been encountered in the centers, Ulucak, and Çukuriçi, in

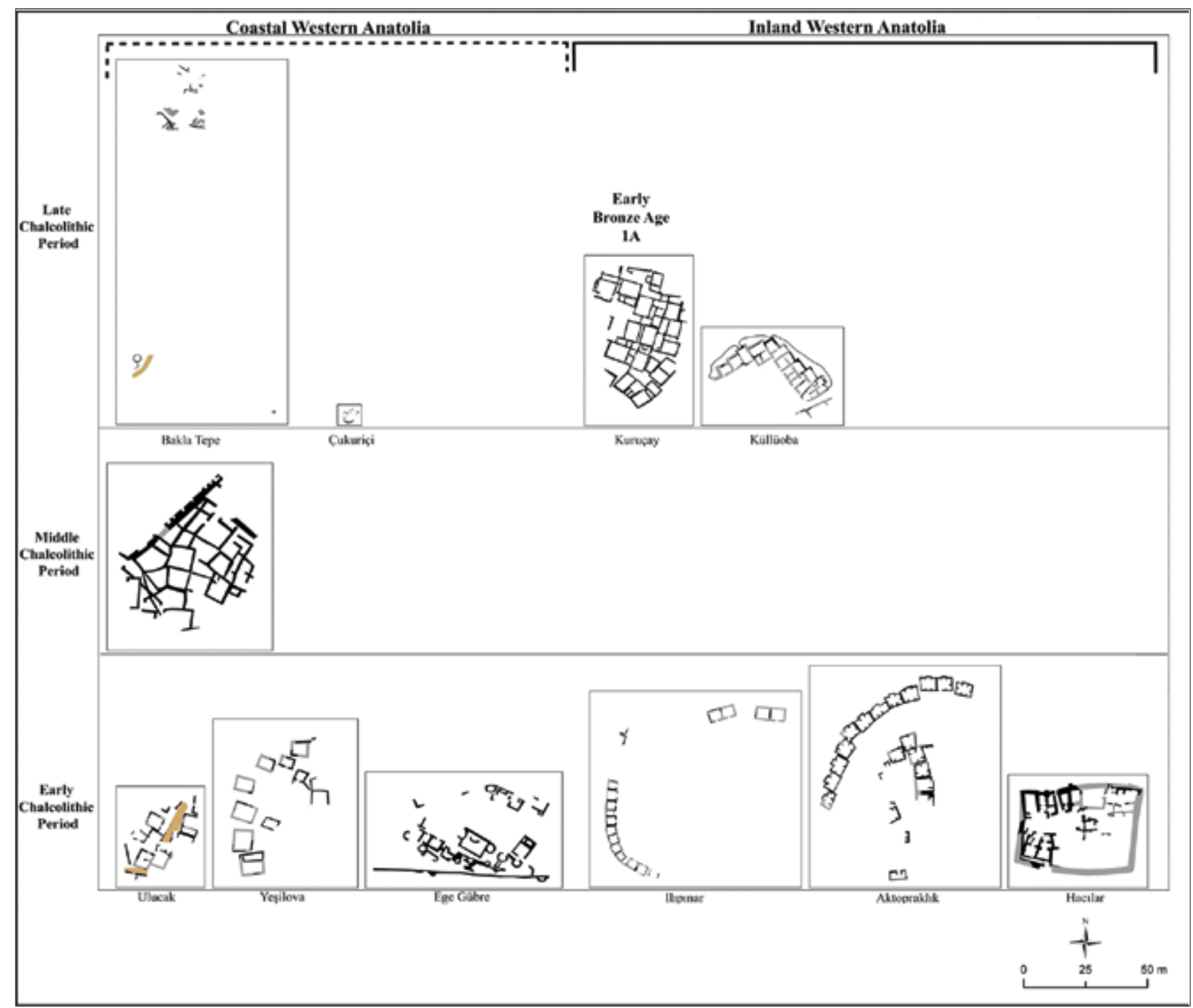

Figure 2: Chalcolithic Age settlements patterns in Coastal and Inland Western Anatolia (Derin 2005, fig. 3; Derin 2020, fig. 3; Duru 1996, pl. 32, 34; Duru 2016, resim 95; Fidan 2012, resim 7; Karul 2017, fig. 112a; Mellaart 1970, fig. 21, 26; Özdoğan 2013, fig. 100, 103; Roodenberg 2003, fig. 1; Sağlamtimur and Ozan 2012, fig. 1; Schwall 2018, abb. 34, 39; Takaoğlu and Özdemir 2013, res. 2)/ Batı Anadolu sahil kesimi ve İ̧̧ Batı Anadolu'da Kalkolitik Çă̆ yerleşim modelleri

2 Korfmann 1983: 222.

3 Korfmann 1983: 222-225.

4 Fidan 2013.

5 Çilingiroğlu/Dinçer/Uhri/Gürbıyık/Baykara/Çakırlar 2016. 
Coastal Western Anatolia. Ulucak Va and $\mathrm{Vb}$ phases can be evaluated within the Neolithic Age. While the houses were built adjacent to each other in the Ulucak Va, the buildings in the $\mathrm{Vb}$ were built independently from each other ${ }^{6}$.

In Central Anatolia and the Lakes District, there is a quite a different settlement plan in the Neolithic Age.

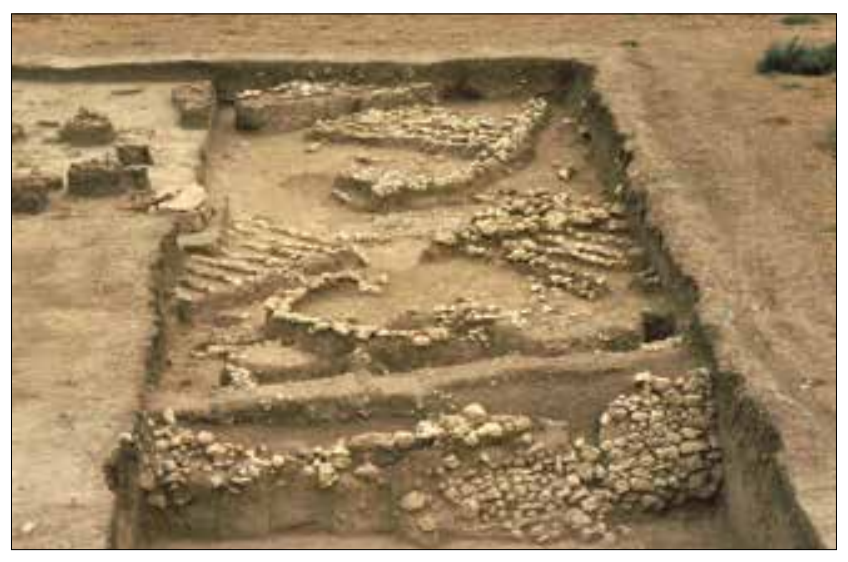

Figure 3: Grill and apsidal planned houses of Bakla Tepe (Photo by Prof. Dr. Hayat Erkanal, Archive of IRERP) / Bakla Tepe, ızara ve apsidal planl yapılar

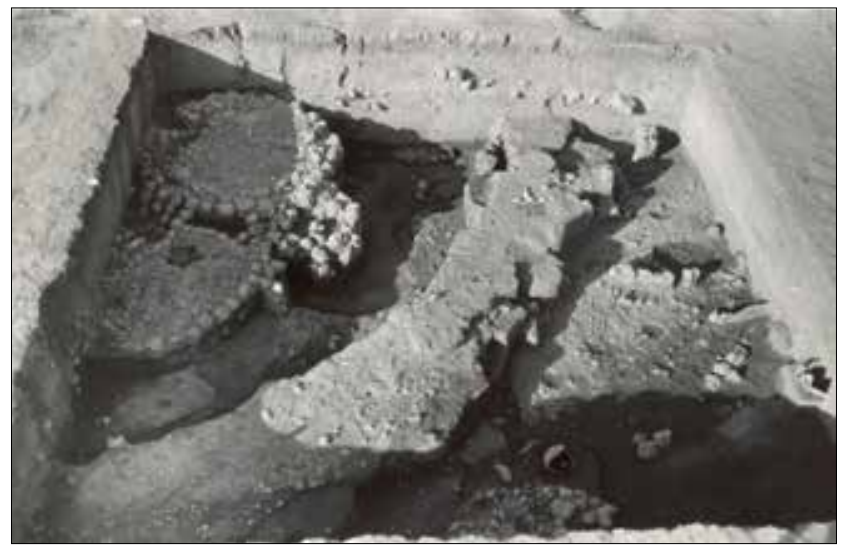

Figure 4: The stone-paved street of Bakla Tepe (Photo by Prof. Dr. Hayat Erkanal, Archive of IRERP) / Bakla Tepe'nin taş döşeli caddesi

The single-room buildings in Bademağacı are scattered and do not have a specific layout ${ }^{7}$. In Aşıkl, groups of structures built adjacently form neighborhoods. In between some of these neighborhoods, there are streets 1 $\mathrm{m}$ in width ${ }^{8}$. While structures that rest on one another are seen in Erbaba ${ }^{9}$ and Çatalhöyük ${ }^{10}$, groups of structures

\footnotetext{
Erdoğu/Çevik 2015: 34-35.

Duru 2016: resim 95.

8 Özbașaran 2012: Fig. 8-10; 2013: 5.

9 Bordaz/Bordaz 1982: pl. XXXIII.

10 Hodder 2006: Fig. 37.
}

built similarly by leaning each against another open onto two square-shaped courtyards via passageways or streets in Can Hasan III ${ }^{11}$.

Early Chalcolithic period in Western Anatolia ${ }^{12}$, a street and structures built in the technique of mudbrick superstructure on stone foundation opening onto the street appear for the first time starting from layer IV of Ulucak ${ }^{13}$. However, a different settlement pattern is observed in Ege Gübre ${ }^{14}$ and Yeşilova ${ }^{15}$, located in the vicinity of Ulucak. In Ege Gübre, buildings are located in a central courtyard surrounded by a perimeter wall ${ }^{16}$, one-room structures lined side by side surround a central courtyard in Yeşilova ${ }^{17}$ (Fig. 2).

In the Early Chalcolithic period, lined-up buildings whose outer sides constitute a part of the defense system in Aşağ 1 Pinar $^{18}$ in Thrace Region, in Ilıpınar ${ }^{19}$ and Aktopraklık ${ }^{20}$ in Marmara Region - Inland Western Anatolia open onto a central courtyard. In Central Anatolia and Lake District buildings open onto a courtyard located in the center like Tepecik-Çiftlik III ${ }^{21}$ and Hacılar IIa and IIb $^{22}$.

Regarding the Middle Chalcolithic period, no distinct settlement plan can be spoken of in Coastal Western Anatolia, as only a limited number of sites have been unearthed, of which the architectural remains could not be completely revealed due to the excavations performed in narrow spaces. In Western Anatolia, Gülpınar is the center where a settlement pattern has been completely uncovered attributed to the time period termed the Middle Chalcolithic period. The pattern in the settlement of Gülpınar consists of a structure with a stone-paved floor, located in the center, and structures joining the one in the center, built in the form of a honeycomb. This type of settlement pattern, similar to the settlement layout seen in Central Anatolia from the Neolithic Age, appears for the first time in Coastal Western Anatolia. The existence of a defense system with protrusions on the sides, which was built thicker than the housing walls, demonstrate a closed settlement pattern surrounded by a defense system in Gülpınar $^{23}$ (Fig. 2).

\footnotetext{
11 Düring 2016: Fig. 4.6.

12 Çevik/Erdoğu 2019.

13 Çilingiroğlu/Çevik/Çilingiroğlu 2012: Fig. 3; Derin, 2005: Fig. 3.

14 Sağlamtimur/Ozan 2012: 230, Fig. 1i

15 Derin/Caymaz 2014: çiz. 2

16 Sağlamtimur/Ozan 2012: 230, Fig. 1; Erdoğu/Çevik 2015: 36.

17 Derin/Caymaz 2014: çiz. 2; Erdoğu/Çevik 2015: 36.

18 Özdoğan 2013: Fig. 100, 103.

19 Roodenberg 2003: Fig. 1.

20 Karul 2017: Fig. 112a.

21 Bıçakçı/Balc1/Altunbilek-Algül 2009: 207; Bıçakçı, Godon/ Çakan 2012, Fig. 3, 6.

22 Düring 2016: Fig. 5.12; Mellaart 1970: Fig. 21, 26.

23 Takaoğlu/Özdemir 2013: res. 2
} 
In Central Anatolia in the Middle Chalcolithic period, there are structures opening onto a central courtyard in layer I of Köşk Höyük ${ }^{24}$, whereas it could be mentioned that there are buildings divided by streets in Güvercinkayas ${ }^{25}$.

Insufficient research of the Late Chalcolithic period in Coastal Western Anatolian settlements and the fact that the related cultural layers are reached in narrow areas at the centers excavated have impeded the revealing of the settlement pattern. However, particularly the excavations conducted in wider areas at Bakla Tepe give an idea about the settlement planning system of the region. Grill, apsidal, rectangular, and elliptic structures have been unearthed in the excavations conducted at Bakla Tepe (Fig. 3, 4). These freestanding structures are situated at intervals on a wider area in Bakla Tepe. The traffic and the connection between the buildings are provided by alleys paved with pebbles (Fig. 4). The fact that the settlement spread across a wide area without a defense system demonstrates that the settlement of the period at Bakla Tepe had an open layout ${ }^{26}$. The existence of grill planned structures at Liman Tepe ${ }^{27}$ and Çukuriçi ${ }^{28}$, which are contemporary with Bakla Tepe and located in the vicinity, shows that they may have a similar settlement planning system to that of Bakla Tepe.

In the Late Chalcolithic period- Early Bronze Age 1A for Inland Western Anatolia ${ }^{29}$ - while a settlement layout consisting of buildings that lean against the zigzagging mudbrick fortification wall and open onto a courtyard in the center is seen at Küllüoba ${ }^{30}$ in Inland Western Anatolia, the settlement plan includes alleys between buildings for passage in phase 6A2 of Kuruçay in the Lakes District. However, these streets were closed with partition walls in phase $6 \mathrm{~A} 1^{31}$.

Düring 2016: Fig. 6.11.

25 Gülçur/Firat 2005: Fig. 1.

26 Erkanal/Özkan 1999; Tuğcu 2019; Şahoğlu/Tuncel 2014.

27 Erkanal/Aykurt/Böyükulusoy/Tuğcu/Tuncel/Şahoğlu 2016: res. 8; Tuncel/Şahoğlu 2018. Liman Tepe excavations is continuing within the course of the Izmir Region Excavations and Research Project (IRERP) under the framework of Ankara University Mustafa V. Koç Research Center for Maritime Archaeology. (ANKÜSAM) and is generously supported by the Ministry of Tourism and Culture, Turkey; Ankara University Scientific Research Fund Project No. 2006 - 0901024, 10Y6055002 and 15A0759003, TÜBITAK, Project No. 108K263; 114K266, Institute for Aegean Prehistory (INSTAP), Ankara University, Dil ve Tarih Coğrafya Fakültesi; INSTAPSCEC; İzmir Metropolitan Municipality, Urla Municipality; Çeşme Municipality, Turkish Historical Society (TTK) and Turkish Institute of Nautical Archaeology (TINA). For more information on ANKÜSAM and the IRERP Project see http:// ankusam.ankara.edu.tr.

28 Schwall 2018: abb. 34, 39.

29 Efe/Türkteki 2011: 189-190.

30 Fidan 2013: 117.

31 Duru 1996: pl. 32, 34.
By the beginning of the $3^{\text {rd }}$ millennium $\mathrm{BC}$, emerging political and social changes seen in Coastal Western Anatolia had led up to the radical changes in the planning system of the settlements. The enclosure of the settlements by defense systems had constricted the areas remaining within the fortification walls, and consequently led to the construction of adjoining houses and the shared-use of the mid-walls for the purpose of fitting more buildings into a narrower space. The traffic and the connection between the structures had continued to be provided by alleys. This settlement layout had become particularly popular in Coastal Western Anatolia and the Eastern Aegean Islands, and was implemented to all of the settlements in the $3^{\text {rd }}$ millennium BC.

Considering Bakla Tepe as an example of the coastal region settlements of Western Anatolia, the settlement pattern of the late architectural phases (BT IV 1 A-B-C) of Bakla Tepe's layer IV consists of long houses and a megaron (House-4) which lie perpendicular or parallel to the defense system. These structures, which extend perpendicular or parallel to the defense system, constitute four building blocks in the east, west, north and south, and the houses in these blocks open onto two streets that run in the north-south direction, and onto shorter alleys connected to these streets (Fig. 5).

During the first half of the $3^{\text {rd }}$ millennium $\mathrm{BC}$, houses located in Coastal Western Anatolia in Troia ${ }^{32}$, Beşik-

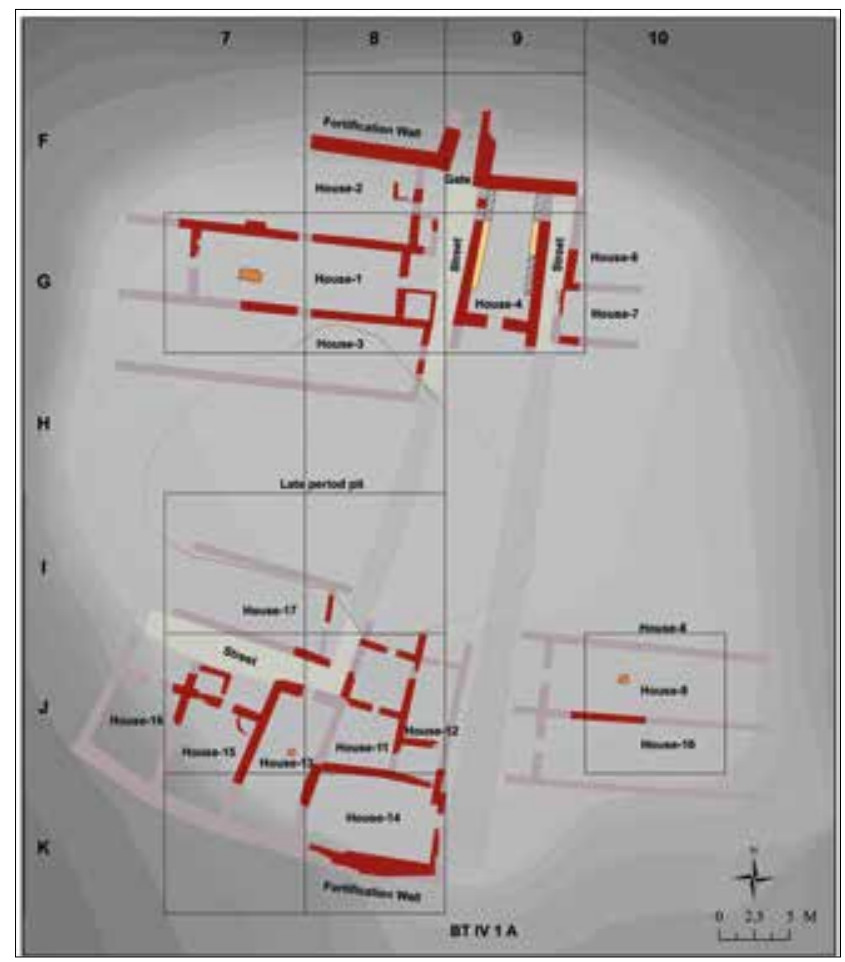

Figure 5: Bakla Tepe phase BT IV 1 A, schematic plan of the settlement / Bakla Tepe'nin BT IV 1 A evresi, yerleşimin şematik planı

32 Ivanova 2013: Fig. 5. 


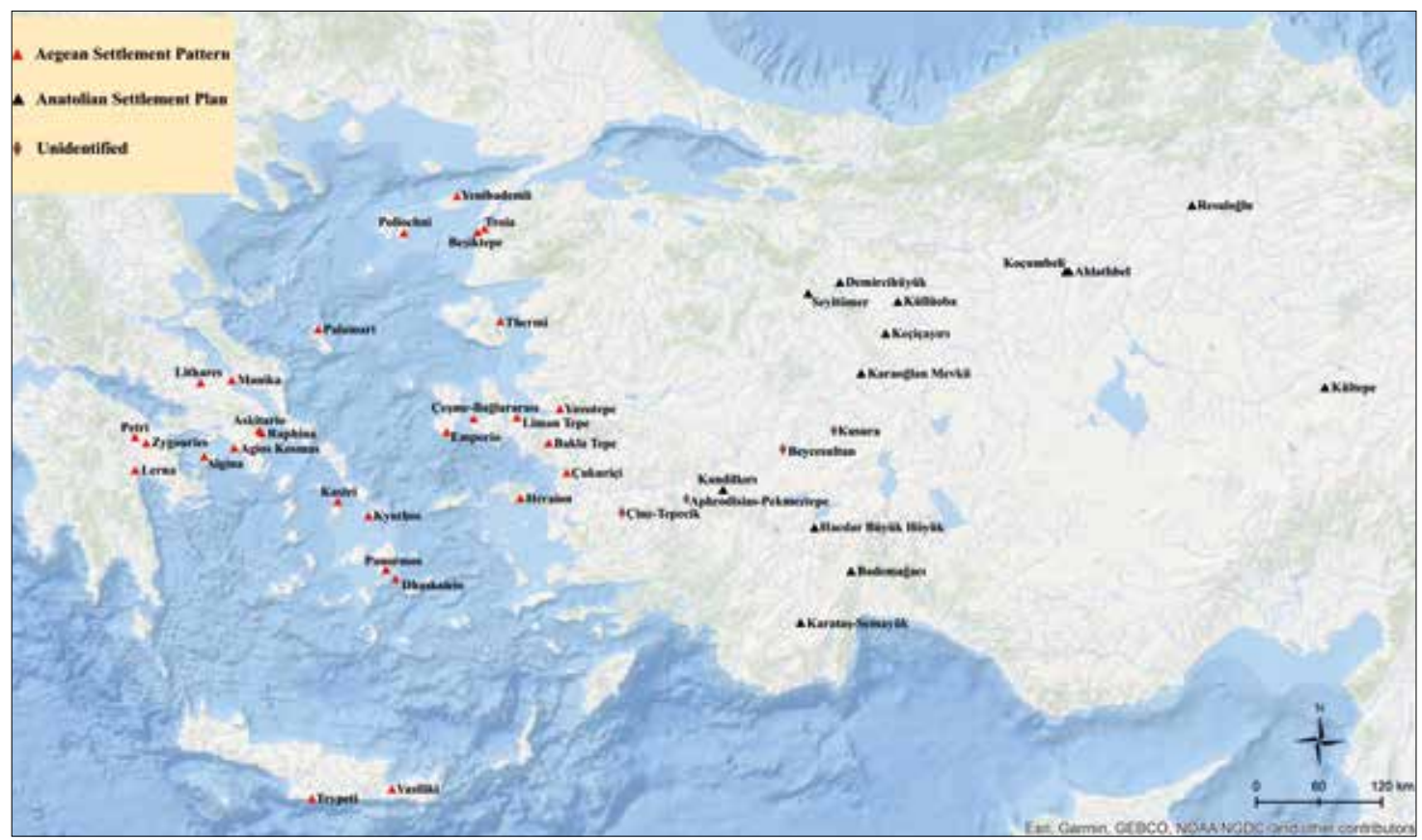

Figure 6: Distribution of "Aegean Settlement Pattern" and "Anatolian Settlement Plan" in the 3rd millennium BC / MÖ 3. Binyıl'da "Ege Yerleşim Modeli" ve "Anadolu Yerleşim Planı" nın Dağılımı

Tepe $^{33}$, Yass1-Tepe ${ }^{34}$, Liman Tepe ${ }^{35}$, Bakla Tepe ${ }^{36}$, Çukuriçi $^{37}$ and on the Eastern Aegean Islands in Poliochni $^{38}$, Yenibademli Höyük ${ }^{39}$, Thermi ${ }^{40}$, Emporio ${ }^{41}$ and Heraion $^{42}$ ? present a similar settlement pattern, by opening onto streets and alleys (Fig. 6,7).

However, in Inland Western Anatolia that was interrelated with Coastal Western Anatolia in the $3^{\text {rd }}$ millennium $\mathrm{BC}$, the settlement pattern which opened onto a central courtyard and was in use since the Early Chalcolithic period had continued to be used ${ }^{43}$. The houses that lean on the defense system in Demircihüyük ${ }^{44}$, Küllüoba ${ }^{45}$, Keçiçayır1 $^{46}$, Büyük Hacılar Höyük ${ }^{47}$, Bademağac1 ${ }^{48}$ and Karataş-Semayük ${ }^{49}$ open onto a central courtyard located in the center. In the second quarter of the $3^{\text {rd }}$ millennium

\footnotetext{
33 Korfmann 1987: 132-33.

34 Derin/Caymaz 2014: çiz. 3.

35 Erkanal/Şahoğlu 2012: 222.

36 Gündoğan/Şahoğlu/Erkanal 2019: Fig. 8-10; Erkanal/Özkan 1999: 25.

37 Horejs/Stefan/Maria 2017: Fig. 5.1.

38 Kouka 2002: plan 3.

39 Hüryılmaz 2013:185, çiz. 4.

40 Kouka 2002: plan 5; Lamb/Brock 1933: 148-51.

41 Hood 1981: 116, Fig. 61.

42 Kouka 2013: 576; 2015: 226-27.

43 Fidan 2013

${ }^{44}$ Korfmann 1989: Fig. 2.

45 Fidan 2013: 117.

46 Fidan 2016: Fig. 6.

47 Umurtak/Duru 2014: 4.

48 Duru/Umurtak 2011: res. 1.

49 Mellink/Angel 1973: Fig. 1.
}

$\mathrm{BC}$, phase $\mathrm{V}$ of Karataş-Semayük ${ }^{50}$ differs clearly from those of Inland Western Anatolia in terms of both structures types and settlement patterns (Fig. 6,7).

Significant changes occur in Anatolia by the second half of the $3^{\text {rd }}$ millennium $\mathrm{BC}$. In this period, called the “Anatolian Trade Network", international trade activities take place within the region extending from Mesopotamia to the Balkans ${ }^{51}$. The hierarchical structuring that began in the Early Bronze Age I gain momentum during this period $^{52}$. The most significant characteristic of the period is the presence of public buildings in the settlement. In Coastal Western Anatolia, in layers Troia II-III, ${ }^{53}$ Liman Tepe V-IV ${ }^{54}$, Çeşme-Bağlararası $3^{55}$ and on the Eastern Aegean Islands in layers Red and Yellow of Poliochni ${ }^{56}$ and Thermi IV-V ${ }^{57}$ streets and alleys improve and remain in existence. In layer of Troia III, the structures, which were built adjacent to one another, open onto streets and alleys. The street that was in use during the Early Bronze Age I continue to be used with some improvements in layers $\mathrm{V}$ and IV of Liman Tepe. In the center of the settlement, there is a public building, and located east of the building is a main street to which alleys are connected. The adjoining long houses seen in the Early Bronze Age I remain present in this period as well and open onto the

\footnotetext{
Wo Warner 1994: pl. 12, 13, 22.

5 Şahoğlu 2005.

52 Gündoğan/Şahoğlu/Erkanal 2019.

53 Melleart 1959: Fig. 10; Ünlüsoy 2018: Fig. 12.

54 Erkanal/Şahoğlu 2016: Fig. 11.

55 Şahoğlu/Çayır/Gündoğan/Tuğçu 2018.

56 Cultraro 2007: Fig. 7. I; Kouka 2002: plan 8-9.

57 Kouka 2002: 27, 30.
} 


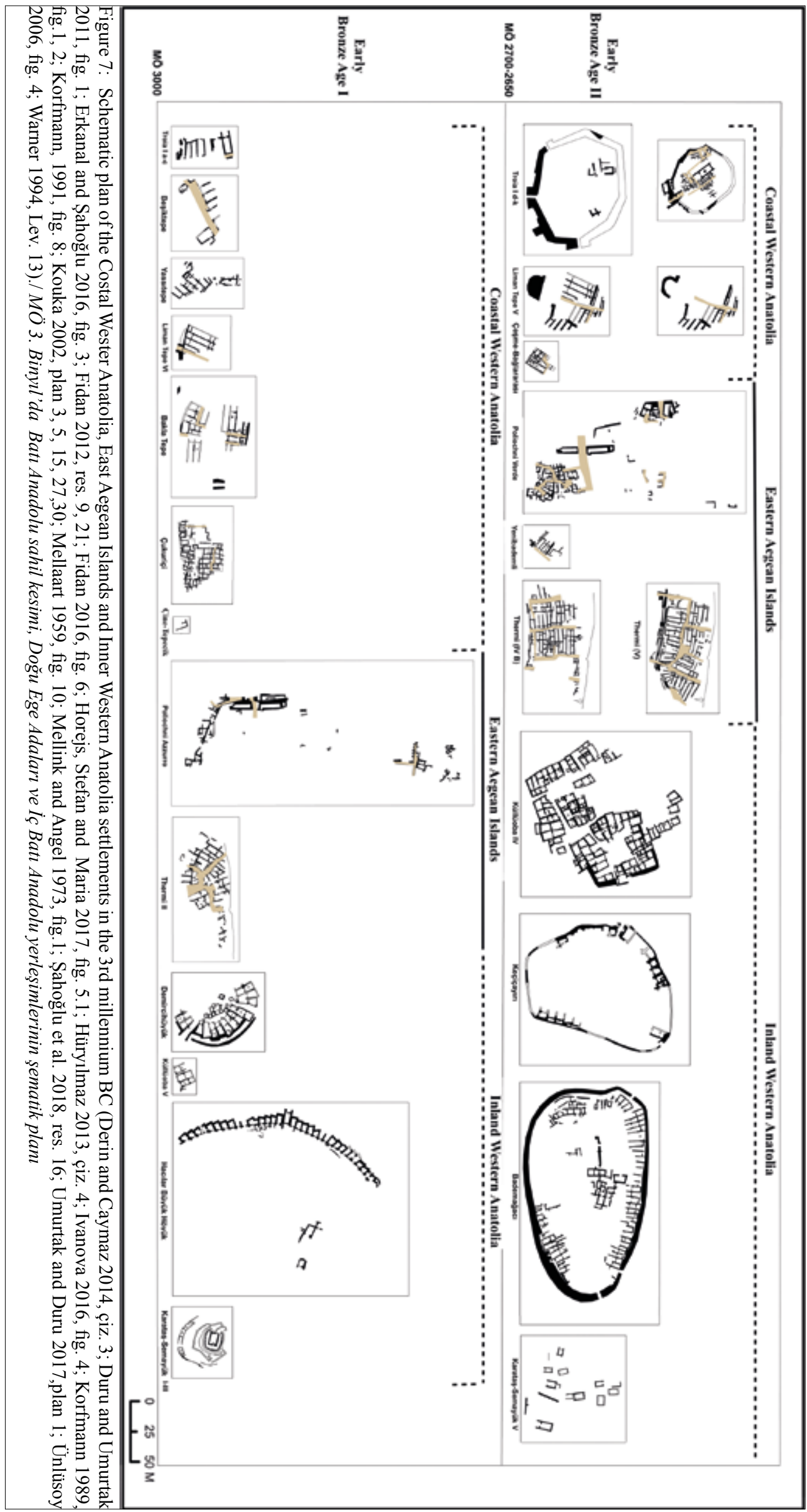


main street and the alleys ${ }^{58}$ (Fig. 8). The long houses and the apsidal and trapezoidal structures that span a couple of layers in Çeşme-Bağlararası open onto a street that begins from the seaside and zigzags its way towards the inner parts ${ }^{59}$ (Fig. 9). The settlement pattern, which includes streets and alleys and continues its existence in Coastal Western Anatolia and the Eastern Aegean Islands, is also seen in settlements in Manika ${ }^{60}$, Lithares $^{61}$, Askitario $^{62}$, Raphina ${ }^{63}$, Petri ${ }^{64}$, Zygouries ${ }^{65}$, Lerna ${ }^{66}$ and Agios Kosmas ${ }^{67}$ in Mainland Greece, in Palamari ${ }^{68}$ on the Sporades, in Agina ${ }^{69}$, Kastri ${ }^{70}$, Kynthos ${ }^{71}$, Panormas ${ }^{72}$ and Dhaskalio $^{73}$ on the Cyclades, and in Trypeti and Vasiliki ${ }^{74}$ on Crete, during the second half of the $3^{\text {rd }}$ millennium BC.

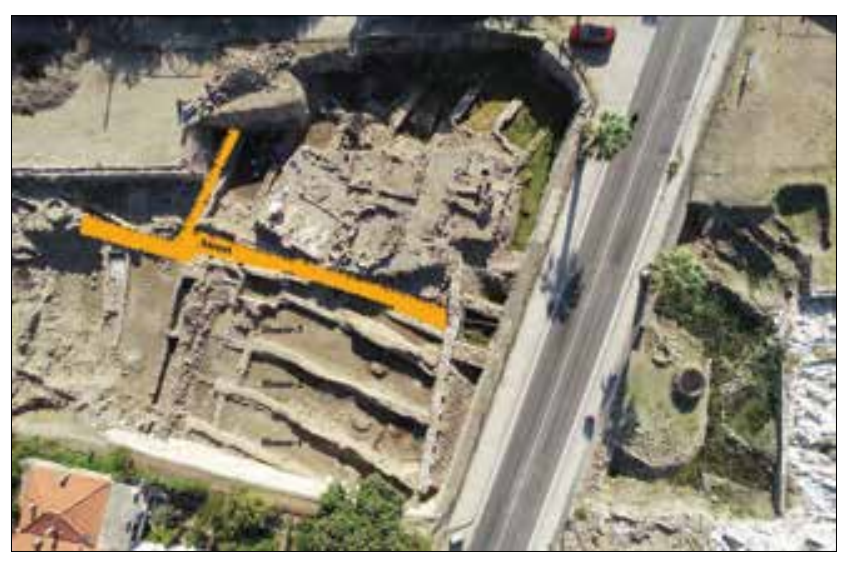

Figure 8: Liman Tepe settlement in the 3rd millennium BC, (Photo by Prof. Dr. Vasıf Şahoğlu, Archive of IRERP) / MÖ 3. Binyıl'da Liman Tepe yerleşimi

The settlement plan, which has been carried out in accordance with the Anatolian settlement pattern that was in use since the Chalcolithic Age in Inland Western Anatolia continues to exist. The most important centers of this period are Seyitömer and Bademağac1. In

\footnotetext{
58 Erkanal/Aykurt/Böyükulusoy/Tuğcu/Tuncel/Şahoğlu 2016: res. 6.

59 Şahoğlu/Çayır/Gündoğan/Tuğcu 2018.

60 Ivanova 2008: tafel 21.

${ }_{61}$ Tzavella Evjen 1985: Fig. 5.

62 Harrison 1995: Fig. 4.

63 Harrison 1995: Fig. 10; Ivanova 2008: tafel 4.

${ }^{64}$ Kostoula 2004: 1138, tafel 1.b.

65 Weiberg 2007: Fig. 21.

66 Alram Stern 2004: tafel 29

67 Harrison 1995: Fig. 5; Mylonas 1959: plan 1.

68 Romanou 2012: Fig. 1.

69 Walter/Felten 1981: Fig. 22.

70 Ivanova 2008: tafel 13; Stampolidis/Sotirakopoulou 2011: Fig. 1.

${ }^{71}$ MacGillivray 1980: Fig. 1.

72 Stampolidis/Sotirakopoulou 2011: Fig. 2.

73 Renfrew/Philaniotou/Brodie/Gavalas 2009: 40, plate 4:b.

74 Watrous 1994: Fig. 7, 9.
}

layers V/A-B of Seyitömer, an independent megaronplanned structure is located within a central courtyard and, opening onto this courtyard, there are adjoining structures that have shared mid-walls ${ }^{75}$. However, in Bademağac1, rectangular, single- or double-roomed adjoining structures that lean against the defense system open onto an oval-shaped central courtyard. Inside this courtyard is also a public building built with addedon, adjacent walls ${ }^{76}$. During this period, small rural settlements also remained in existence ${ }^{77}$. The settlement pattern with a central courtyard, which is used in Inland Western Anatolia, is also seen in Central Anatolia. Such structures, which have central courtyards and are surrounded by defense systems, appear in Ahlatlibel ${ }^{78}$, Koçumbeli $^{79}$, Kültepe ${ }^{80}$ and Resuloğlu ${ }^{81}$ in the second half of the $3^{\text {rd }}$ millennium $\mathrm{BC}$.

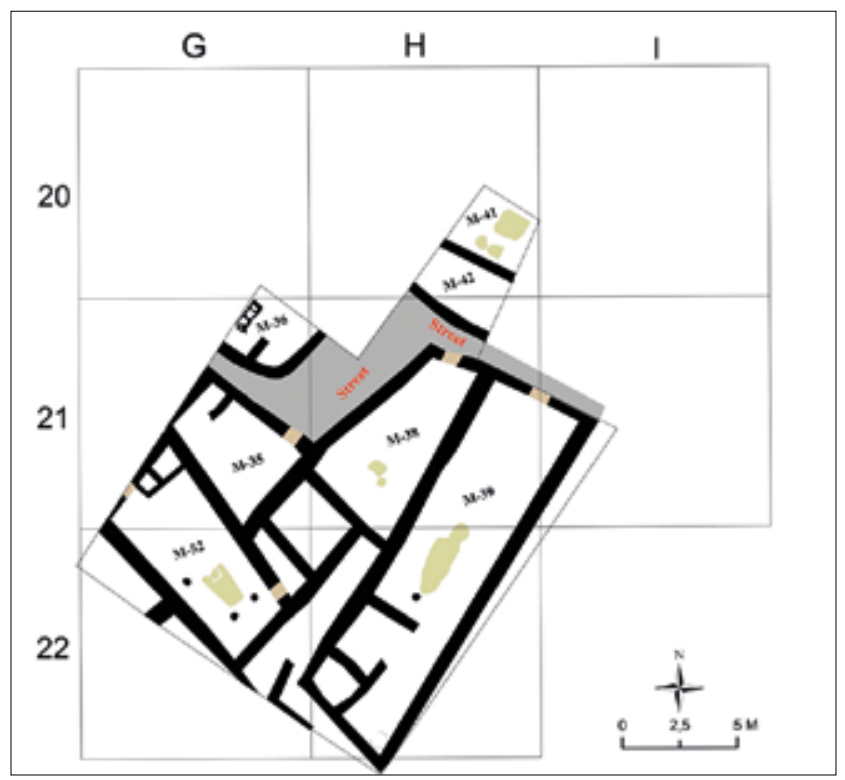

Figure 9: Çeşme-Bağlararası 3, schematic plan of the settlement / Çeşme-Bağlararası 3, yerleşimin şematik planı

\section{CONCLUSION}

Since the Neolithic Age, different architectural development and settlement pattern processes have been observed in Coastal Western Anatolia and Inland Western Anatolia region. The most significant factor for the differences seen in the planning systems among the

\footnotetext{
75 Bilgen/Bilgen/Çırakoğlu 2015: 119-30, Fig. 139-140.

${ }_{76}$ Duru/Umurtak 2007; 2011, res. 1; 2016, 76.

77 Oğuzhanoğlu 2019: res. 7.

78 Koşay 1934: 7; Tuna/Buluç/Tezcan 2012: Fig.1.

79 İlgezdi-Bertram/Bertram 2012: 118-119, Fig.3; Tuna/Buluç/ Tezcan 2012: Fig.3.

80 Kulakoğlu 2017: 217.

81 Yildırım 2013: plan 1; Y1ldırım/Kısa 2015, 100.
} 
coastal settlements and the Inland Western Anatolian settlements should be the climate, geographical conditions, and the sources of livelihood. The difference in the settlement patterns can be explained by climate and geography as the climate becomes more continental the closer, we get from the coast to the inner regions. By separating the settlement structures with narrow streets and alleys, it could be intended to provide some kind of air circulation between the streets, in the coastal regions where the climate is warmer.

Settlement layouts play an active role in establishing cultural boundaries, just as they may contribute to determining the sociological behavior of societies. When the existing settlement plans, which are unearthed in Anatolia and which have been determined by climate, geography and culture, are compared, it is possible to say that rather than individuality unity was more prominent in the settlements assembled around central courtyards. The shared central courtyard, instead of belonging to a particular class, must have been available to all the individuals residing in the settlement. The workflow that occurred at the central courtyard could also have been oriented around a common interest. Even though the activities that require collective workforce, such as the construction of long house blocks divided by streets and alleys, communal defense systems and streets, have been performed through common action, individuality is at the forefront rather than unity. Settlements that include streets and alleys are comparably more functional than settlements that have central courtyards. While it could be possible to expand the settlement and extend the streets and the alleys by abandoning a part of the existing fortification wall and building an additional one, as in Green (Verde) period of Poliochni, at the settlements which have streets and alleys ${ }^{82}$, the expansion of the residential areas of the settlements that have central courtyards could be very challenging and require a need for more materials and workforce.

Arranging the settlement around a central courtyard must have been related to more of a cultural approach rather than the size or the dimensions of the settlement. Streets and alleys may not have been needed in lowdensity settlements. That said, even though the Coastal Western Anatolian settlements of the period were of the same size as their contemporary Inland Western Anatolian settlements, the houses were still separated from each other by streets and alleys. The difference, in terms of settlement patterns and structure types, between these two contemporary regions that had been in mutual interaction, must result from the understanding of architectural culture.

82 Cultraro 1997: 98.
Korfmann, as a result of the excavations he carried out in Demircihüyük, and based on the Demircihüyük settlement pattern, had used the term, "Anatolian Settlement Plan"83. It has become possible to outline the cultural borders in Anatolia using the settlement patterns, by the beginning of the $3^{\text {rd }}$ millennium BC. In Coastal Western Anatolia, the houses surrounded by the defense systems display a settlement pattern that opens onto streets and alleys, in the beginning of the $3^{\text {rd }}$ millennium BC. Even though, in layers I-II of Karataş-Semayük in Mediterranean region, a settlement pattern that opens onto a central courtyard is observed, it exhibits a distinctive character in terms of building types. Layers III-V of Karataş-Semayük, however, are distinguished from the surrounding cultural regions by both its individually located megarons and apsidal structures, and its settlement patterns ${ }^{84}$. In Inland Western Anatolia and Central Anatolia, structures that lean on the defense system open onto central courtyards and create a pattern named "Anatolian Settlement Plan". The architecture of Demircihüyük reflects the finest example of the Anatolian settlement plan. Even though the layout of Pulur-Sakyol ${ }^{85}$ in Eastern Anatolia resembles the Demircihüyük plan, the existence of the structures that are located on the streets in layer VI B2 of Malatya-Arslantepe ${ }^{86}$, which is contemporary with and close to this settlement, diverges from the settlement plan of Pulur-Sakyol ${ }^{87}$. Outside of Anatolia, buildings that open onto central courtyards are seen in Thrace Region as well. ${ }^{88}$ In this context, the term "Anatolian Settlement Plan" contradicts Korfmann's "Anatolian Settlement Plan" in that it does not embrace all of Anatolia but only Inland Western Anatolia and Central Anatolia, and that there are different settlement patterns in Coastal Western Anatolia and the Mediterranean Region.

Fidan reassesses Korfmann's term, “Anatolian Settlement Plan", and states that the term applies only to Inland Western Anatolia. ${ }^{89}$ When the "Anatolian Settlement Plan" is reviewed, it could be seen that such settlements built actually in accordance with this plan are found in Inland Western Anatolia ${ }^{90}$. However, there exists structures that lean against defense systems and open onto central courtyards located in the center in Central Anatolia in Ahlatlıbel ${ }^{91}$, Koçumbeli, ${ }^{92}$ Kültepe $^{93}$ and Resuloğlu ${ }^{94}$ in the $3^{\text {rd }}$ millennium BC. In this context, contrary to

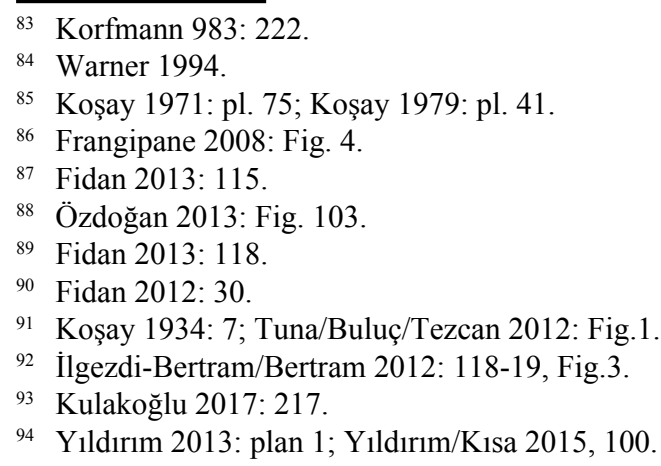


Korfmann's statement, the "Anatolian Settlement Plan" should include Central and Inland Western Anatolia, and not all of Anatolia. Central Anatolia should be included within the area circumscribed by Fidan as Inland Western Anatolia, as well.

As mentioned above, in the $3^{\text {rd }}$ millennium $\mathrm{BC}$, the structuring of the settlements in Coastal Western Anatolia, the Eastern Aegean Islands, the Cyclades, Crete and Mainland Greece evolved into a settlement pattern that is based on streets and alleys. Particularly, when taking into consideration the trade and cultural relations between Coastal Western Anatolia, the Eastern Aegean Islands, the Cyclades, Crete and Mainland Greece in the $3^{\text {rd }}$ millennium BC, it could be seen that a cultural-architectural concept emerged within the region surrounded by the Aegean Sea. The term, the "Aegean Settlement Pattern", could be used for such settlements built based on this concept.

The "Aegean Settlement Pattern", which appear in Early Chalcolithic period and complete its development in the $3^{\text {rd }}$ millennium $\mathrm{BC}$, continue to exist in the Middle Bronze Age, the Late Bronze Age, and the Iron Age, as well.

\section{ACKNOWLEDGEMENTS}

I would like to express my deepest gratitudes to late Prof. Dr. Hayat Erkanal who accepted my participation in the IRERP Project and continuously supported me throughout my career. I also would like to thank my mentor Prof. Dr. Vasıf Şahoğlu for his support and permission to use archaeological data from Liman Tepe, Bakla Tepe and Çeşme - Bağlararası excavations.

\section{REFERENCE}

ALRAM-STERN, E. 2004.

Die Ägäische Frühzeit 2. Band-Teil 1 \& 2. Die Frübronzezeit in Griechenland. Wien.

BIÇAKÇI, E./BALCI, S./ALTINBİLEK-ALGÜL, Ç. 2009. “Tepecik-Çiftlik 2007 Yılı Çalışmaları”, KST 30/4: 205218.

BIÇAKÇI, E./GODON, M./ÇAKAN, Y. G. 2012.

"Tepecik-Çiftlik", The Neolithic in Turkey Central Turkey (Eds. M. Özdoğan/B. Nezih/K. Peter), İstanbul: 89134.

BİLGEN, N./BİLGEN, Z./ÇIRAKOĞLU, S. 2015.

"Seyitömer Erken Tunç Çă̆ı Yerleşimi V. Tabaka", Seyitömer Höyük I (Ed. N. Bilgen), İstanbul: 119-186.

BORDAZ, J./BORDAZ, L. A. 1982.

"Erbaba: The 1977 and 1978 Seasons in Perspective", Türk Arkeoloji Dergisi 26/1:85-93.

CULTRARO, M. 1997.

"Nuovi dati sul Periodo Verde di Poliochni", Poliochni e l'antica età del bronzo nell'Egeo settentrionale, Convegno Internzionale, Atene 22-25 Aprile, 1996 (Eds.

C. Doumas/V. La Rosa), Athens: 98-119.

CULTRARO, M. 2007.

"Domestic architecture and public space in Early Bronze Age Poliochni (Lemnos)', Building Communities: House, Settlement and Society in the Aegean and Beyond (Eds. R. Westgate/N. Fisher/J. Whitley), London: 55-64.

ÇEVİK Ö./ERDOĞU B. 2019.

"Multiple Faces of Changes in 5600/5500 cal. BC Anatolia and Thrace”, Anatolica 45: 1-16.

ÇILINGGiROĞLU, A./ÇEVIK, Ö./ÇILINGIROĞLU, Ç. 2012.

"Ulucak Höyük", Ege Üniversitesi Arkeoloji Kazıları (Eds. A. Çilingiroğlu/Z. Mercangöz/G. Polat), İzmir: 157168.

ÇİLINGIROĞLU Ç./DINNÇER, B./UHRİ, A./GÜRBIYIK, C./BAYKARA, I./ÇAKIRLAR, C. 2016.

"New Palaeolithic and Mesolithic Sites in the Eastern Aegean: the Karaburun Archaeological Survey Project", Antiquity 90/353: 1-6.

DERIN, Z. 2005.

"The Neolithic Architecture of Ulucak Höyük", Byzas 2: 85-94.

DERIN, Z./CAYMAZ, T. 2014. 
“İmir’in Prehistorik Yerleşim Alanı-Yeşilova Höyüğü 2012 Yılı Çalışmaları”, KST 35/1: 419-433.

DURU, R. 1996.

Kuruçay Höyük 2: Geç Kalkolitik ve İlk Tunç Çağı Yerleşmeleri 1978-1988 Kazılarının Sonuçları, Ankara.

DURU, R. 2016.

Tarım'dan 'Yazı'ya Burdur Yöresi ve Yakın Çevresi’nin Altıbin Yılı (MÖ 8000 - MÖ 2000), Antalya.

DURU, R./UMURTAK, G. 2007.

"Bademă̆acı Kazllarl 2006 Yllı Çalışmalarl-

Excavations at Bademağacı in 2006”, ANMED 5: 6-11.

DURU, R./UMURTAK, G. 2011.

"Bademăgacl 2010 Yllı Kazllarl-Excavations at Bademă̆acı in 2010”, ANMED 9: 7-15.

DURU, R./UMURTAK, G. 2016.

“Bademă̆acı Höyüğü”, Antalya Kültür ve Turizm Dergisi 27: 70-81.

DURING, B. 2016.

Küçük Asya'nın Tarihöncesi: Karmaşık AvcıToplayıcalardan Erken Kentsel Toplumlara (A. Keskin, Trans.), İstanbul.

EFE T./TÜRKTEKİ M. 2011.

"İç Batı Anadolu Bölgesi: Giriş", Karşıdan Karşıya: MÖ 3. Bin' de Kiklad Adaları ve Batı Anadolu (Eds. V. Şahoğlu/P. Sotirakopoulou), İstanbul: 186-191.

ERDOĞU B./ÇEVİK Ö. 2015.

"Batı Anadolu Kronolojisi ve Terminolojisi: Sorunlar ve Öneriler”, APAD 1: 29-45.

ERKANAL，H./AYKURT, A./BÖYÜKULUSOY, K./ TUĞCU, İ./TUNCEL, R./ŞAHOĞLU, V. 2016.

"Liman Tepe 2014 Yllı Kara ve Sualtı Kazllarl”, KST 37/1: 323-340.

ERKANAL H./ ÖZKAN T. 1999.

"Bakla Tepe Kazlları", Tahtalı Barajı Kurtarma Kazıları Projesi / Tahtalı Dam Area Salvage Project, (Eds. T. Özkan/H. Erkanal), İzmir: 12-41.

ERKANAL, H./ŞAHOĞLU, V. 2012.

“Liman Tepe (1992-)”, Dil ve Tarih-Coğrafya Fakültesi 75. Yıl Armağanı Arkeoloji Bölümü, Tarihcesi ve Kazıları (1936-2011), Anadolu-Anatolia Ek Dizi III. 2, 219-230.
ERKANAL, H./ŞAHOĞLU, V. 2016.

"Liman Tepe, an Early Bronze Age Trade Center in Western Anatolia: Recent Investigations”, Early Bronze Age Troy: Chronology, Cultural Development and Interregional Contacts, Proceedings of an International Conference held at the University of Tübingen May 8-10, 2009 (Eds. E. Pernicka/S. Ünlüsoy/W. Blum), Bonn: 157-166.

FIDAN, E. 2012.

“Küllüoba İlk Tunç Çă̆ı Mimarisi”, MASROP 7: 1-44.

FIDAN, E. 2013.

"Anadolu Yerleşim Planı Üzerine Yeni Bir Değerlendirme”, Ege Ünivarsitesi Edebiyat fakültesi Arkeoloji Dergisi XVIII: 113-125.

FIDAN, E. 2016.

"Keçiçayırı: an Early Bronze Age II Fortified Hilltop Settlement (North-West Anatolia)", Mediterranean Archaeology and Archaeometry 16/1: 87-99.

FRANGIPANE, M. 2008.

"The Arslantepe Royal Tomb: New Funerary Customs and Political Changes in the Upper Euphrates Valley at the Beginning of the Third Millennium BC", Scienze dell'Antichità, 14/1: 169-194.

GÜLÇUR, S./FIRAT, C. 2005.

"Spatial Analysis of Güvercinkayası, A Middle Chalcolithic Hilltop Settlement in Northwestern Cappadocia: A Preliminary Report", Anatolia Antiqua XIII, 41-52.

GÜNDOĞAN,Ü./ŞAHOĞLU, V./ERKANAL, H. 2019. "Spatial Organization and Production Activities at Bakla Tepe during the First Half of the 3rd Millennium", DTCF Dergisi 59/2: 1087-1110.

HARRISON, S. 1995

"Domestic Architecture in Early Helladic II: Some Observations on the Form of Non-Monumental Houses", The Annual of the British School at Athens 90: 23-40.

HODDER, I. 2006.

Çatalhöyük Leoparın Öyküsü (D. Şendil, Trans.), İstanbul.

HOOD, S. 1981.

Excavations in Chios 1938-1955: Prehistoric Emporio and Ayio Gala vol/1, Athens.

HOREJS, B./STEFAN, G./MARIA, R. 2017.

"Continuity and Change in an Early Bronze Age 1 Metal Workshop”, Çukuriçi Höyük 1 Anatolia and the Aegean from the 7th to the 3rd Millennium BC (Ed. 
B. Horejs). Vienna: 95-125.

HÜRYILMAZ, H. 2013.

“Gökçeada-Yenibademli Höyük 2011 Yllı Kazlları”, KST 34/1: 169-186.

HÜRYILMAZ, H. 2017.

“Erken Tunç Çă̆ı'nda Kuzey ve Doğu Ege Denizi Adalart: Yerleşim Yerleri, Yaşamsal Kaynaklar ve Kültürel İlişkiler”, Anadolu, Arkeoloji, Zaman ve Mekan: Dumlupınar Üniversitesi V. Arkeoloji Sempozyumu, Kütahya, 10-12 Ekim 2016 (Ed. G. Coşgun), Ankara: 1-14.

IVANOVA, M. 2008.

Befestigte Siedlungen auf dem Balkan, in der Ägäis und in Westanatolien, ca 5000 - 2000 v. Chr. Münster.

IVANOVA, M. 2013.

"Domestic Architecture in the Early Bronze Age of Western Anatolia: the Row-houses of Troy I", Anatolian Studies 63: 17-33.

İLGEZDİ-BERTRAM G./BERTRAM, J. K. 2012. "Ankara Bölgesi'nde İlk Tunç Çă̆l Yerleşimleri", Türkiye'de Arkeometrinin Ulu Çınarları Prof. Dr. Ay Melek Özer ve Prof. Dr. Şahinde Demirci’ye Armağan (Eds. A. A. Akyol/ K. Özdemir), İstanbul: 117-124.

KARUL, N. 2017.

Aktopraklık: Tasarlanmış Prehistorik Bir Köy, İstanbul.

KORFMANN, M. 1983.

Demircihüyük I: die Ergebnisse der Ausgrabungen 1975-1978: Architektur, Stratigraphie und Befunde, Mainz am Rhein.

KORFMANN, M. 1987.

“Beşik-Yassıtepe, 1986 Kazı Raporu”, KST 9/1: 131134.

KORFMANN, M. 1989.

“Ausgrabungen am Besik-Tepe 1982-1987”, Anatolia and the Ancient Near East. Studies in Honor of Tahsin Özgüç (Eds. K. Emre/B. Hrouda/M. Mellink/N. Özgüç), Ankara: 271-78.

KOSTOULA, M. 2004.

"Die Ausgrabungen in der frühhelladisch Siedlung von Petri bei Nemea”, Die Ägäische Frühzeit 2. Band-Teil 1 \& 2. Die Frübronzezeit in Griechenland (Ed. E. Alram-Stern), Wien: 1135-1158.

KOŞAY, H. Z. 1934.

“Ahlatlıbel Hafriyatı”, Türk Tarih, Arkeoloji ve
Etnografya Dergisi 2: 3-101.

KOŞAY, H. Z. 1971.

"Pulur (Sakyol) Kazısl 1969. Keban Projesi 1969 Çalışmaları", Orta Doğu Teknik Üniversitesi Keban Projesi Yayınları I/2: 99-106.

KOŞAY, H.Z. 1979.

"Keban'ın Pulur (Sakyol) Höyüğ̈̈ Kazısında Bulunan Kutsal Ocaklar" 8. Türk Tarih Kongresi 1: 77-80.

KOUKA, O. 2002.

Siedlungsorganisation in der Nord- und Ostägäis während der Frühbronzezeit (3. Jt. v.Chr.) (Vol. 58). Raden Westfalia.

KOUKA, O. 2013.

"Minding the Gap": Against the Gaps. The Early Bronze Age and the Transition to the Middle Bronze Age in the Northern and Eastern Aegean/Western Anatolia", American Journal of Archaeology 117/4, 569-580.

KOUKA, O. 2015.

"Prehistoric Heraion Reconsidered: Glimpses on the Excavations 2009-2013 North of the Sacred Road", Ein Minoerim Exil, Festschrift für Wolf-Dietrich Niemeier. Universitätsforschungen zur Prähistorischen Archäologie (Eds. D. Panagiotopoulos/I. Kaiser/O. Kouka), Bonn: 223-242.

KOUKA, O. 2016.

"The Embodiment of Land Ownership in the Aegean Early Bronze Age", An archaeology of prehistoric bodies and embodied identities in the Eastern Mediterranean (Eds. M. Mina/S. Triantaphyllou/Y. Papadatos), Oxford: 129-135

KULAKOĞLU, F. 2017.

"Early Bronze Age Monumental Structures at Kültepe", Proceedings of the 2nd Kültepe international meeting, Kültepe/ KIM 2 (Eds. F. Kulakoğlu/G. Barjamovic), Subartu XXXIX. Turnhout: 217-227.

LAMB, W./BROCK, J. K. 1933.

"Excavations at Thermi", Annual of the British School at Athens 31: 148-165.

MACGILLIVRAY, J. A. 1980.

"Mount Kynthos in Delos. The Early Cycladic Settlement", Bulletin de correspondance hellénique 104/1: 3-45.

MELLAART, J. 1959.

"Notes on the Architectural Remains of Troy I and II", Anatolian Studies 9: 131-62. 
MELLAART, J. 1970.

Excavations at Hacılar I-II: Edinburgh.

MELLINK, M. J./ANGEL, J. L. 1973.

"Excavations at Karataş-Semayük and Elmall, Lycia 1972”, American Journal of Archaeology 77/3: 293307.

MYLONAS, G. 1959

Aghios Kosmas : an Early Bronze Age Settlement and Cemetery in Attica, Princeton.

OĞUZHANOĞLU, U. 2019.

"Batı Anadolu Erken Tunç Çă̆l Yerleşim Modeline Dair Yeni Gözlemler: Laodikeia-Kandilkırı 2. Tabaka”, 15. Yılında Laodikeia (2003-2018) (Ed. C. Şimşek), İstanbul: 239-252.

ÖZBAŞARAN, M. 2012.

"Aşıklı" The Neolithic in Turkey Central Turkey (Eds. M. Özdoğan/B. Nezih/P. Kuniholm), İstanbul: 135-158.

ÖZBAŞARAN, M. 2013.

"Orta Anadolu'nun Neolitikleşme Sürecinde Aşıklı", Colloquium Anatolicum XII: 1-15.

ÖZDOĞAN, M. 2013.

"Neolithic Sites in the Marmara Region: Fikirtepe, Pendik, Yarımburgaz, Toptepe, Hoca Çeşme and Aşağ Pınar" The Neolithic in Turkey: Northwestern Turkey and Istanbul (Eds. M. Özdoğan/B. Nezih/P. Kuniholm), İstanbul: 167-269.

RENFREW, C./PHILANIOTOU, O./BRODIE, N./ GAVALAS, G. 2009.

"The Early Cycladic Settlement at Dhaskalio, Keros: Preliminary Report of the 2008 Excavation Season”, Annual of the British School at Athens 104: 27-47.

ROMANOU, C. 2015.

"The Fortification of Palamari". The Fortified Prehistoric Settlement in Palamari, Skyros, Proceedings of the Interdisciplinary Meeting for the Project of Excavation and Presentation Athens, October 23-24, 2012 (Eds. L. Parlama/M. Theochari/C. Romanou/S. Bonatsos), Arhens: 2-22.

ROODENBERG, J. (2003).

“2001 Yllı Ilıpınar Kazı Sezonu”, KST 14/1: 461-464.

SAĞLAMTIMUR, H./OZAN, A. 2012.

"Ege Gübre Neolitik yerleşimi”, Ege Üniversitesi Arkeoloji Kazıları (Eds. A. Çilingiroğlu/ Z. Mercangöz/ G. Polat), İzmir: 223-241.
SCHWALL, C. 2018.

Çukuriçi Höyük 2: Das 5. und 4 Jahrtausend v. Chr. Westabatolian und der Ostagais, OREA 7. Wien

STAMPOLIDIS, N./SOTIRAKOPOULOU, P. 2011.

"Erken Kiklad Mimarisi", Karşıdan Karşıya: MÖ 3. Bin'de Kiklad Adaları ve Batı Anadolu (Eds. V. Şahoğlu/P. Sotirakopoulou), İstanbul: 32-40.

ŞAHOĞLU, V. 2005.

"The Anatolian Trade Network and the Izmir Region during the Early Bronze Age”, Oxford Journal of Archaeology 24/4: 339-361.

ŞAHOĞLU, V./ÇAYIR, U./GUNDOĞAN, U./TUĞCU, I. 2018.

"Çeşme-Bağlararası: Batı Anadolu Sahil Kesiminde Bir Tunç Çağı Yerleşimi”, Anadolu/Anatolia 44: 371-389.

\section{ŞAHOĞLU V./TUNCEL R. 2014.}

"New insights into the Late Chalcolithic of coastal western Anatolia: A view from Bakla Tepe, Izmir" Western Anatolia before Troy: Proto-Urbanisation in the 4th Millennium BC?: Proceedings of the International Symposium held at the Kunsthistorisches Museum Wien, 21-24 November 2012 (Ed. B. Horejs), Vienna: $65-82$.

TAKAOĞLU, T./ÖZDEMIR, A. 2013.

"Smintheion Öncesi: Prehistorik Yerleşim", Smintheion, Apollon Smintheus' un İzinde (Ed. Ö. Coşkun), İstanbul: 1529.

TUĞCU İ. 2019.

"Bakla Tepe Geç Kalkolitik Çă̆ Mimarisi", Cevat BAŞARAN'a 60. Yaş Armağanı- Essays for Cevat BAŞARAN's 60 ${ }^{\text {th }}$ Birthday Occasion (Eds. V. Keleş/H. Kasapoğlu/H.E. Ergürer/E. Çelikbaş/A. Yılmaz), Ankara: 421-438.

TUNA, N./BULUÇ, S./TEZCAN, B. 2012. OTDÜ Arkeoloji Müzesi/ The METU Museum of Archaeology, Ankara.

TUNCEL R./ŞAHOĞLU V. 2018.

"The Chalcolithic of Coastal Western Anatolia: A view from Liman Tepe, Izmir", Communities in Transition: The Circum-Aegean Area During the 5th and 4th Millennia BC (eds, S. Dietz/F. Mavridis/Z. Tankosic/T. Takaoğlu), Oxford: 513-529.

TZAVELLA-EVJEN, H. 1985.

Lithares: An Early Bronze Age Settlement in Boeotia Vol. 15: Los Angeles. 
UMURTAK, G./DURU, R. 2014.

“Hacılar Büyük Höyük Kazıları 2013”, Arkeoloji ve Sanat 145: 1-20.

UNLUSOY, S. 2018.

"İlk Tunç Çağları Boyunca Batı Anadolu'da Toplumsal Değişim”, Cedrus VI: 105-124.

WALTER, H./FELTEN, F. 1981.

Alt-Ägina 3/1: Die vorgeschichtliche Stadt. Befestigungen, Häuser, Funde, Mainz am Rhein.

WARNER, J. 1994.

Elmalı-Karataş 2: The Early Bronze Age Village of Karataş, Bryn Mawr.

WATROUS, L. V. 1994.

"Review of Aegean prehistory III: Crete from earliest prehistory through the protopalatial period", American Journal of Archaeology 98/4: 695-753.

WEIBERG, E. 2007.

Thinking the Bronze Age, Life and Death in Early Helladic Greece, Uppsala.

YILDIRIM, T. 2013.

"Resuloğlu 2012 Yılı Çalışmaları", Çorum Kazı ve Araştırmalar Sempozyumu 3: 5-11.

YILDIRIM, T./KISA, A. 2015.

“Çorum/Resuloğlu 2014 Yllı Çalışmaları", Çorum Kazı ve Araştırmalar Sempozyumu 5: 97-104. 